\title{
Pengembangan Media Komik IPA Model PBL untuk Meningkatkan Kemampuan Berfikir Analitis dan Sikap Ilmiah
}

\author{
Devy Indah Lestari ${ }^{1}{ }^{*}$, Anti Kolonial Projosantoso ${ }^{2}$ \\ ${ }^{12}$ Program Studi Pendidikan Sains, Program Pascasarjana, Universitas Negeri Yogyakarta. Jalan \\ Colombo No. 1, Karangmalang, Yogyakarta, 55281, Indonesia \\ * Korespondensi Penulis. Email: vee_dh@yahoo.co.id, Telp: +62274-550836
}

\begin{abstract}
Abstrak
Penelitian ini bertujuan untuk mengetahui: (1) karakteristik, (2) kriteria kelayakan, dan (3) keefektifan media komik model PBL pada pembelajaran IPA di SMP kelas VII dalam meningkatkan kemampuan berfikir analitis dan sikap ilmiah. Penelitian ini merupakan penelitian dan pengembangan yang mengadaptasi model Borg \& Gall yang terdiri dari lima tahap. Subjek coba pada penelitian ini adalah siswa kelas VII di SMP Negeri 1 Sentolo. Pengujian lapangan menggunakan kuasi eksperimen nonequivalent control group design. Hasil penelitian menunjukkan bahwa media pembelajaran IPA berbentuk komik: (1) memiliki karakteristik: alur cerita sesuai sintaks PBL, judul komik merupakan integrasi dari $\mathrm{KD}$ 4.3, KD 7.3, dan KD 7.4, cerita dalam komik memuat indicator berfikir analitis, tokoh dalam komik diperankan melalui sikap ingi tahu dan berfikir terbuka, (2) layak digunakan dengan kriteria sangat baik dan (3) efektif untuk meningkatkan kemampuan berfikir analitis dan sikap ilmiah siswa.
\end{abstract}

Kata Kunci: media komik, kemampuan berfikir analitis, dan sikap ilmiah

\section{Developing Science Comic Media Using the Problem-Based Learning Model to Increase the Analytical Thinking Ability and Scientific Attitude}

\begin{abstract}
This research aims to knows: (1) the characteristic, (2) feasibility, and (3) effectiveness of natural science teaching media in the form of comic using problem-based learning model to increase the analytical thinking ability and scientific attitude of grade VII students of junior high school. This study was research and development adapting the model from Borg \& Gall consisting of five steps. The research subjects were grade VII students of SMP N 1 Sentolo. The main try out used quasiexperimental with the nonequivalent control group design. The results of this research show that (1) the characteristic of comic media are: has a stories according the syntax of Problem Based Learning model, integrated title of KD 4.3, KD 7.3, and KD 7.4, the stories in comics load indicator analytical thinking ability, and the characters in the comics through scientific attitude of curiosity and open minded thinking, (2) the developed science teaching media in the form of comic is in a very good quality category, and (3) it is feasable to use to increase the students' analytical thinking ability and scientific attitude. The effectiveness of the developed media to increase the analytical thinking ability and science attitude.
\end{abstract}

Keywords: comic media, analytical thinking ability, and scientific attitude

How to Cite: Lestari, D., \& Projosantoso, A. (2016). Pengembangan media komik IPA model PBL untuk meningkatkan kemampuan berfikir analitis dan sikap ilmiah. Jurnal Inovasi Pendidikan IPA, 2(2), 145-155. doi:http://dx.doi.org/10.21831/jipi.v2i2.7280

Permalink/DOI: http://dx.doi.org/10.21831/jipi.v2i2.7280 


\section{Jurnal Inovasi Pendidikan IPA, 2 (2), 2016 - 146}

Devy Indah Lestari, Anti Kolonial Projosantoso

\section{PENDAHULUAN}

Berkaitan dengan pemenuhan kebutuhan kompetensi abad XXI, UU Sisdiknas memberikan arahan yang jelas tentang tujuan pendidikan yang harus dicapai. Tujuan pendidikan tersebut adalah mewujudkan proses berkembangnya kualitas pribadi siswa yang tidak hanya bermaksud membentuk insan Indonesia yang cerdas, namun juga berkepribadian atau berkarakter, sehingga nantinya akan lahir generasi bangsa yang tumbuh dan berkembang dengan karakter yang bermanfaat pada nilai-nilai luhur yang dimiliki bangsa, negara serta agama. Pendidikan bersifat dinamis, selalu mengalami perubahan secara berkala sesuai dengan kebutuhan dan persaingan global.

Tahun 2013 pemerintah telah melakukan pembaharuan dari kurikulum KTSP menjadi kurikulum 2013. Pada kenyataanya semua instansi pendidikan belum menerapkan Kurikulum 2013. Hanya beberapa sekolah yang ditunjuk dan yang telah siap menerapkan Kurikulum 2013. Hal itu disebabkan masih banyaknya sekolah yang sarana dan prasarananya belum mendukung, distribusi buku siswa, buku guru dan buku penunjang pembelajaran juga belum siap. Baik KTSP maupun Kurikulum 2013 memiliki ciri, kelebihan, dan juga kelemahan. KTSP merupakan kurikulum yang merefleksikan pengetahuan, keterampilan, dan sikap sehingga dapat meningkatkan potensi siswa secara optimal. Penekanan KTSP adalah pada pengembangan kemampuan melakukan (kompetensi) dan tugas-tugas dengan standar performansi tertentu, sehingga hasilnya dapat dirasakan oleh siswa berupa penguasaan terhadap seperangkat kompetensi tertentu (Hamriah, 2013, p.340).

Sesuai tuntutan Kurikulum, IPA diajarkan secara terpadu artinya tidak dipisahkan antara fisika, biologi, dan kimia (Kemendikbud, 2013, p.iii). Pembelajaran terpadu dalam IPA dapat dikemas dengan suatu tema, dibahas dari berbagai sudut pandang atau disiplin kelimuan. IPA di SMP/MTs pada hakikatnya merupakan cara mencari tahu tentang alam secara sistematis, sehingga IPA bukan hanya penguasaan kumpulan pengetahuan yang berupa fakta-fakta, konsep-konsep, atau prinsip-prinsip saja tetapi juga merupakan suatu proses penemuan dalam kehidupan sehari-hari.

Alam sebagai objek kajian IPA dikaji melalui observasi dan eksperimen yang menghasilkan data, bukti yang kuat dan kesimpulan yang dapat dipercaya hingga menjadi suatu penge- tahuan yang dapat diprediksi dan diaplikasikan dalam masyarakat. Selanjutnya IPA tidak hanya terbatas sebagai pengetahuan saja, melainkan memiliki empat dimensi IPA yaitu IPA sebagai cara berfikir, IPA sebagai cara investigasi, IPA sebagai batang tubuh pengetahuan, dan IPA memiliki interaksi dengan teknologi dan masyarakat. IPA merupakan suatu sistem untuk mengetahui tentang alam melalui pengumpulan data dari observasi dan eksperimen (Chiappetta \& Koballa, 2010, p.102).

Selanjutnya hakikat IPA menurut (Kemendikbud,2013,p.213) meliputi empat unsur yaitu: (1) Sikap: rasa ingin tahu tentang benda, fenomena alam, makhluk hidup, serta hubungan sebab akibat yang menimbulkan masalah baru yang dapat dipecahkan melalui prosedur yang benar; IPA bersifat open ended; (2) Proses: prosedur pemecahan masalah melalui metode ilmiah; metode ilmiah meliputi penyusunan hipotesis, perancangan eksperimen atau percobaan, evaluasi, pengukuran, dan penarikan kesimpulan; (3) Produk: berupa fakta, prinsip, teori, dan hukum; (4) Aplikasi: penerapan metode ilmiah dan konsep IPA dalam kehidupan sehari-hari.

Pendidikan IPA di Indonesia masih perlu terus diperbaiki kualitasnya. Peningkatan kualitas pendidikan IPA dapat dilaksanakan di antaranya dalam bentuk pengembangan metode penyampaian materi pembelajaran, pengembangan kurikulum, serta pengembangan berbagai jenis media pembelajaran. Salah satu bagian integral dari upaya pembaharuan berupa inovasi media pembelajaran. Tumbuhnya kesadaran terhadap pentingnya pengembangan media pembelajaran di masa yang akan datang harus dapat direalisasikan dalam bentuk nyata (Widyawati \& Prodjosantoso, 2015, p. 25).

Hasil survey Programe for International Student Assessment (PISA) di bawah Organization Economic Cooperation and Development (OECD) pada tahun 2012 lalu, disebutkan bahwa kemampuan matematika siswa-siswi di Indonesia menduduki peringkat bawah dengan skor 375 dari skor maksimum 613. Bidang kemampuan membaca mendapatkan skor 396 dari skor maksimum 570 dan di bidang kemampuan sains mendapatkan skor 382 dari skor maksimum 580 (OECD, 2013, pp.31-221). Disebutkan juga bahwa PISA mengukur kecakapan anak-anak usia 15 tahun dalam menerapkan kemampuan matematika, sains, dan membaca untuk memahami persoalan di dunia nyata. Secara umum hasil PISA memberikan gambaran mengenai tingkat 
literasi dalam ketiga aspek itu. Soal-soal dalam PISA menekankan assessment atas kemampuan menalar dan kecakapan berpikir. Siswa diharapkan tidak hanya sekedar tahu dari mana pengetahuan diperoleh, tapi juga dapat menguji dengan baik bagaimana siswa dapat meramalkan dan menerapkan pengetahuan yang mereka miliki baik di dalam sekolah maupun dalam kehidupan di luar sekolah (OECD, 2013, p.24). Berdasarkan penilaian PISA tersebut, menunjukkan bahwa kemampuan berfikir siswa di Indonesia untuk memecahkan suatu persoalan di dunia nyata belum dapat dikuasai. Guru harus lebih banyak melatih siswa agar memiliki kemampuan berfikir dalam menyelesaikan permasalahan yang berkaitan dengan kehidupan sehari-hari.

Permasalahan pembelajaran IPA juga ditemukan di SMP Negeri 1 Sentolo. Berdasarkan hasil observasi pada bulan Oktober 2014 dan wawancara dengan guru IPA kelas VII dapat diketahui bahwa kemampuan pemahaman siswa terhadap IPA belum merata, hal itu nampak ketika diadakan evaluasi pada akhir sub bab maupun evaluasi tengah semester, beberapa siswa yang memperoleh nilai di atas KKM adalah siswa yang sama dengan evaluasi sebelumnya. Sebagian besar siswa belum mencapai KKM, sehingga harus dilakukan kegiatan remidial. Rata-rata nilai UN mata pelajaran IPA masih berada di peringkat ke tiga setelah Bahasa Indonesia dan Bahasa Inggris.

Aktivitas belajar IPA di SMP N 1 Sentolo seperti percobaan, pengamatan, membaca yang sudah dilakukan, juga belum mampu mengembangkan kemampuan siswa dalam menganalisis maupun menguraikan suatu masalah menjadi bagian yang lebih sederhana. Hal ini nampak ketika melakukan kegiatan percobaan maupun pada saat guru memberikan permasalahan, banyak siswa masih kesulitan untuk memecahkan permasalahan yang menghasilkan suatu kesimpulan. Hal tersebut mengindikasikan bahwa kemampuan berfikir analitis siswanya masih rendah.

Salah satu aspek kognitif dalam taksonomi Bloom adalah aspek analisis. Bloom (WCES, 2012,p. 3340), menyebutkan bahwa berfikir analisis merupakan sebuah kompetensi mengidentifikasi dan mengklasifikasi aspek-aspek yang berbeda, yang terdapat pada objek, cerita atau peristiwa, kemudian dapat menemukan hubungan dari komponennya, bagaimana aspek dapat diasosiasikan, menemukan sebab atau dampaknya agar komprehensi dan dapat melihat hubungan antar komponennya. Kemampuan berpikir analisis merupakan suatu kemampuan dasar yang harus dimiliki oleh siswa. Kemampuan berpikir analisis ini tidak mungkin dicapai apabila siswa tidak menguasai aspek kognitif sebelumnya.

Menganalisis berarti memecah materi/ bagian yang kompleks menjadi bagian-bagian yang lebih sederhana yang melibatkan pengelompokkan sesuatu untuk menjelaskan cara kerja, menganalisis hubungan antara bagianbagian, mengenali sebab/motif atau struktur organisasi (Moore, 2009, p. 82). Berfikir analisis menekankan pada uraian materi utama ke dalam pendeteksian hubungan-hubungan setiap bagian yang tersusun secara sistematis. Analisis sebagai suatu tujuan, dapat dibagi menjadi tiga sub kategori, yaitu analisis bagian, analisis hubungan, dan analisis pengorganisasian prinsip (Kuswaya, 2012, p.53).

Menganalisis melibatkan proses memecah-mecah materi menjadi bagian kecil dan menentukan bagaimana hubungan antar bagian dan antara setiap bagian dan struktur keseluruhannya. Menganalisis meliputi proses kognitif membedakan (menentukan potongan informasi yang relevan atau penting), mengorganisasikan (menentukan cara untuk menata potongan informasi tersebut), dan mengatribusikan (menentukan tujuan dibalik informasi tersebut). Berfikir analisis sebagai salah satu tujuan pokok pembelajaran dapat untuk mengembangkan kemampuan siswa dalam hal: membedakan fakta dari opini (realitas dari khayalan); menghubungkan kesimpulan dengan pernyataan pendukungnya; membedakan materi yang relevan dari yang tidak relevan; menghubungkan ide-ide; menangkap asumsi-asumsi yang tak dikatakan dalam perkataan; membedakan ide pokok dari ide turunannya; menemukan bukti pendukung tujuan pengarang (Anderson \& Kratwohl, 2010, p.120). Menurut pendapat dari para ahli, dapat disimpulkan bahwa berfikir analitis merupakan suatu kemampuan untuk menguraikan, merinci menjadi bagian penyusunnya, dapat mencari keterkaitan atau hubungan antara bagian-bagian, dan menentukan bagaimana bagian tersebut berhubungan satu dengan yang lainnya tersebut. Indikator berfikir analisis adalah kemampuan merinci suatu permasalahan, mencari hubungan antar aspek/bagian, kemampuan membedakan, kemampuan mengorganisasikan (menentukan metode, alat dan bahan serta kesimpulan), dan mengkontribusikan (menentukan pendapat/ tujuan dari suatu aktivitas). 


\section{Jurnal Inovasi Pendidikan IPA, 2 (2), 2016 - 148}

Devy Indah Lestari, Anti Kolonial Projosantoso

Proses pembelajaran yang dilakukan guru tidak lepas dari media pembelajaran untuk mendukung tugas guru dalam memotivasi siswa. Media pembelajaran sebagai perantara guru dalam menyampaikan informasi kepada siswa. Media pembelajaran yang efektif adalah media pembelajaran yang dapat membuat siswa senang dalam belajar sehingga siswa lebih mudah memahami materi. Buku IPA yang sebagian besar berisi penjelasan dalam bentuk kalimat panjang dapat membuat siswa bosan. IPA dirasa sebagai pelajaran yang sulit. Media pembelajaran yang dapat membantu siswa memberikan gambaran-gambaran dari materi pada buku teks adalah media pembelajaran visual, salah satunya berbentuk komik. Komik merupakan jenis media dengan kumpulan gambar yang menceritakan peristiwa tertentu. Pengemasan materi IPA dalam bentuk komik sangat menarik.

Definisi komik menurut McCloud (Noll Webb, Balasubramanian, ỎBroin, \& Webb, 2012, p. 106), yaitu "juxtaposed pictorial and other images in deliberate sequence, intend-ed to convey information and or produce an aestethic response in the viewer". Gambargambar yang disusun secara berurutan untuk menyampaikan informasi dan memberikan kesan keindahan kepada para pembaca.

Pemakaian komik dengan ilustrasi berwarna, alur cerita yang ringkas, dengan perwatakan orang yang realistis akan menarik siswa dari berbagai tingkat usia. Selanjutnya (Daryanto, 2010, p.127),mengungkapkan bahwa komik sebagai bentuk kartun yang mengungkapkan karakter dan menerapkan suatu cerita dalam urutan yang erat hubungannya dengan gambar dan dirancang untuk memberikan hiburan kepada pembaca. Komik merupakan bentuk seni yang menggunakan gambar-gambar tidak bergerak yang disusun sedemikian rupa sehingga membentuk jalan cerita dan memberikan pengalaman belajar yang menyenangkan (Nugraha, Yulianti, \& Khanafiyah, 2012, p. 61).

Berdasarkan uraian mengenai definisi komik, dapat disimpulkan bahwa komik merupakan sajian berupa alur cerita yang berisi pesan atau informasi, diperankan oleh para tokoh yang disertai dengan gabungan gambar-gambar dan teks yang berurutan sebagai ekspresi dari pemerannya sehingga pembaca tertarik dan terhibur membaca komik.

Pengembangan media pembelajaran IPA dengan komik, dapat menimbulkan rasa senang pada siswa dan dapat meningkatkan pemahaman siswa terhadap mata pelajaran IPA dalam belajar mandiri. Hasil prasurvai karakteristik siswa kelas VII di SMP N 1 Sentolo, menunjukkan bahwa siswa menginginkan dan senang jika ada media pembelajaran yang baru untuk kegiatan belajar, contohnya media yang lebih bewarna dan bergambar, yang tidak membosankan. Sebanyak 53\% siswa SMP N 1 Sentolo memiliki hobi membaca dan $44 \%$ siswa pernah membaca komik tentang materi pelajaran. Sebanyak 97\% pendapat siswa SMP Negeri 1 Sentolo sangat setuju dan senang jika pembelajaran IPA dikemas berbentuk komik.

Komik sebagai media belajar dapat memicu semangat dan motivasi belajar karena isinya sesuai dengan lingkungan siswa dan dapat mengasah potensi siswa sehingga kelak siswa dapat bersaing pada lingkup internasional. Suatu analisis terhadap bahasa komik oleh Thorndike (Sudjana \& Rivai, 2011, pp.65-68) menunjukkan adanya segi yang menarik. Tampilan komik yang disajikan dalam gambar-gambar berwarna cerah yang dapat membuat siswa tidak bosan dalam membaca, serta dialog bahasa yang digunakan ringan dan sesuai dengan percakapan seharihari sehingga siswa akan lebih mudah dalam memahami pelajaran. Media komik sebagai tempat untuk menampung isi, informasi atau ajaran yang alur ceritanya dipadukan dengan sintaks model pembelajaran PBL. Model ini dipilih karena dalam model PBL menghadirkan suatu permasalahan kontekstual, sehingga membutuhkan kemampuan analisis siswa untuk memecahkan permasalahan tersebut.

Hasil temuan di lapangan menunjukkan bahwa komik yang sudah ada di pasaran, ada yang hanya sebagai pengantar pembelajaran saja dan ada juga yang isinya belum terpadu. Penggunaan komik dalam penelitian ini ditekankan pada seluruh kegiatan pembelajaran sebagai alur pembimbing kegiatan pembelajaran dan sebagai penyedia materi pelajaran. Pada kegiatan awal siswa diberi suatu cerita tentang permasalahan yang merupakan salah satu topik pembelajaran, kemudian siswa diarahkan untuk menganalisis permasalahan tersebut dengan menjawab pertanyaan yang ada pada komik. Selanjutnya siswa juga melakukan serangkaian kegiatan lainnya sesuai dengan instruksi dalam komik. Melalui kegiatan membaca cerita dalam komik, siswa diharapkan mampu menganalisis masalah yang disediakan, guna melatih berkembangnya kemampuan berfikir analitis.

Perwujudan karakter tokoh dalam komik dapat diwujudkan dengan sikap ilmiah, sebagai pengembangan domain sains yaitu ranah sikap. 
Sikap ilmiah dalam dimensi sains yang diintegrasikan dalam pembelajaran IPA dapat memberikan pengalaman yang bermakna bagi siswa karena mereka memahami, mengintegrasikan dan mengaktualisasikannya melalui proses pembelajaran. Dengan demikian, nilai-nilai tersebut dapat terserap secara alami lewat kegiatan sehari-hari.

Kenyataan di SMP N 1 Sentolo sikap ilmiah sudah mulai digali oleh guru, namun masih ada sikap ilmiah yang kurang tampak pada diri siswa yaitu sikap terbuka dan ingin tahu. Ketika pembelajaran berlangsung hanya beberapa siswa saja yang menunjukkan sikap ingin tahunya dengan bertanya, dan siswa yang aktif didominasi oleh siswa tertentu. Ketika kegiatan diskusi nampak ada anggota kelompok yang merasa bahwa jawabannya yang paling benar, sehingga jika ada temannya memberi masukan kurang diperhatikan.

Sikap ilmiah yang diteliti pada penelitian ini adalah sikap ingin tahu dan terbuka. Sikap ingin tahu merupakan rasa keingintahuan lebih banyak mempelajari ilmu pengetahuan (Nur \& Muslimin, 2007.p.29). Lebih lanjut, (Bundu, 2006, p.41) mengatakan sikap ingin tahu (curiosity) ditunjukkan pada perhatian siswa terhadap apa yang ada disekitarnya. Beswick \& Tallmadge (Harty \& Beall, 1984, p. 426) menyatakan bahwa rasa ingin tahu dapat ditafsirkan sebagai dorongan dan kesiapan individu untuk mencari dan memecahkan konflik konseptual. Rasa ingin tahu adalah stimulus untuk penyelidikan. Seseorang yang penasaran/ingin tahu akan bertanya, membaca untuk menemukan informasi dan mudah untuk memulai penyelidikan. Harlen (Fatonah \& Prasetyo, 2014, p. 33) menyebutkan bahwa, seseorang yang memiliki sikap berfikir terbuka akan bisa menghargai pendapat/temuan orang lain, mau merubah pendapat jika terdapat kekurangan data, menerima saran orang lain, tidak merasa selalu benar.

Tema Jernih Airku Sehat Lingkunganku dipilih karena ingin membelajarkan kompetensi dasar mengenai pencemaran lingkungan dan pemisahan campuran. Materi pencemaran lingkungan merupakan materi yang memiliki banyak fenomena atau permasalahan kaitannya dengan lingkungan dan sesuai dengan konteks kehidupan sehari-hari. Berdasarkan fenomena pencemaran lingkungan, siswa akan dihadapkan pada suatu persoalan yang mengajak siswa untuk menganalisis dan memecahkan persoalan, sehingga diharapkan pembelajaran IPA dapat bermakna bagi siswa dalam kehidupannya.

Penelitian ini berusaha memberikan kontribusi dalam pendidikan khususnya pada proses pembelajaran IPA melalui pengembangan media pembelajaran IPA berbentuk komik dengan model PBL tema Jernih Airku Sehat Lingkunganku untuk meningkatkan kemampuan berfikir analitis dan sikap ilmiah siswa kelas VII SMP.

Tujuan penelitian ini untuk: (1) mengetahui karaktersitik media pembelajaran IPA berbentuk komik model PBL dalam meningkatkan kemampuan berfikir analitis dan sikap ilmiah siswa, (2) mengetahui criteria kelayakan media komik dengan model PBL pada pembelajaran IPA di SMP kelas VII yang digunakan untuk meningkatkan kemampuan berfikir analitis dan sikap ilmiah, dan (3) mengetahui keefektifan media komik dengan model PBL pada pembelajaran IPA di SMP kelas VII dalam meningkatkan kemampuan berfikir analitis dan sikap ilmiah.

\section{METODE}

Jenis penelitian ini adalah penelitian dan pengembangan atau Research and Development $(R \& D)$. Model penelitian pengembangan yang dipilih adalah model penelitian dan pengembangan yang dikembangkan oleh (Gall, Gall, \& Borg, 2011, p. 772), dimana penelitian pengembangan merupakan penelitian yang berorientasi untuk mengembangkan dan memvalidasi produk yang dikembangkan. Produk yang dihasilkan pada penelitian ini berupa media pembelajaran IPA berbentuk komik dengan model PBL yang digunakan untuk meningkatkan kemampuan berfikir analitis dan sikap ilmiah siswa kelas VII SMP. Model pengembangan Borg \& Gall dipilih, karena langkah revisi selalu diletakkan setelah tindakan uji dilakukan.

Model pengembangan meliputi sepuluh langkah, yaitu: (1) research and information collecting; (2) planning; (3) develop primary form of product(4) preliminary field testing product; (5) main product revision; (6) main field testing;(7) operational product revision; (8) operational field testing; (9) final product revision; dan (10) dissemination and implementtation (Gall et al., 2011, pp. 775-789).

Waktu dan tempat penelitian dilaksanakan di SMP N 1 Sentolo yang dilaksanakan pada bulan April hingga Mei 2015. Sampel dalam penelitian ini adalah kelas VII B dan VII C SMP N 1 Sentolo yang diambil dengan teknik random sampling. 
Prosedur pengembangan dalam penelitian ini mengacu pada tahapan model pengembangan (Gall et al., 2011, p. 772). Gambar 1 menjelaskan prosedur pengembangan yang dilakukan oleh peneliti.

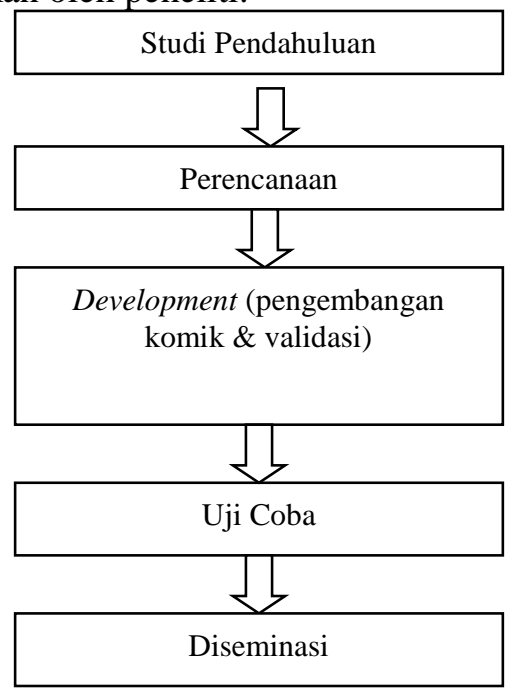

Gambar 1.Modifikasi Prosedur Pengembangan Komik

\section{Instrumen dan Teknik Pengumpulan Data}

Teknik pengumpulan data pada penelitian ini yaitu dengan observasi, wawancara, pengisian lembar kuesioner, dan tes tertulis. Sedangkan instrument yang digunakan dalam penelitian ini meliputi lembar validasi produk, lembar observasi sikap ilmiah, angket respon siswa, dan butir-butir soal kemampuan berfikir analitis.

\section{Teknik Analisis Data}

Analisis data deskriptif yaitu pada data kelayakan komik dan respon siswa terhadap komik. Data kelayakan komik didapatkan dari penilaian ahli, guru IPA, dan teman sejawat, sedangkan data respon siswa didapatkan dari pengisian lembar kuesioner respon siswa setelah pembelajaran menggunakan komik.

Analisis kelayakan produk komik, dilakukan dengan cara menghitung skor rata-rata dari setiap aspek penilaian menggunakan rumus:

$$
\overline{\mathrm{X}}=\frac{\sum \mathrm{X}}{\mathrm{n}}
$$

Keterangan:

$\bar{X}=$ Rerata skor

$\sum X=$ jumlah skor tiap aspek

$\mathrm{n}=$ jumlah responden

Skor yang diperoleh kemudian dikategorikan menggunakan skala lima (Azwar, 2011, p. 63). Produk dikatakan layak digunakan jika memiliki kriteria minimal baik. Rerata data pe- nilaian kelayakan produk dikonversi berdasarkan skala 5 (Azwar, 2011, p. 163).

Tabel 1. Konversi Skor Penilaian Komik Oleh Validator

\begin{tabular}{|c|c|c|c|c|}
\hline No & Interval & & Nilai & Kategori \\
\hline 1 & $\mathrm{X}>\mathrm{Yi}+1,5 \mathrm{Sbi}$ & $X>4$ & $\mathrm{~A}$ & $\begin{array}{c}\text { Sangat } \\
\text { Baik }\end{array}$ \\
\hline 2 & $\begin{array}{l}\mathrm{Yi}+0,5 \mathrm{Sbi}<\mathrm{X} \\
\leq \mathrm{Yi}+1,5 \mathrm{Sbi}\end{array}$ & $\begin{array}{l}3,3< \\
X \leq 4\end{array}$ & B & Baik \\
\hline 3 & $\begin{array}{l}\mathrm{Yi}-0,5 \mathrm{Sbi}<\mathrm{X} \\
\leq \mathrm{Yi}+0,5 \mathrm{Sbi}\end{array}$ & $\begin{array}{c}2,7< \\
X \leq \\
3,3\end{array}$ & C & Cukup \\
\hline 4 & $\begin{array}{l}\mathrm{Yi}-1,5 \mathrm{Sbi}<\mathrm{X} \\
\leq \mathrm{Yi}-0,5 \mathrm{Sbi}\end{array}$ & $\begin{array}{l}2<X \\
\leq 2,7\end{array}$ & $\mathrm{D}$ & $\begin{array}{l}\text { Tidak } \\
\text { Baik }\end{array}$ \\
\hline 5 & $\mathrm{X} \leq \mathrm{Yi}-1,5 \mathrm{Sbi}$ & $X<2$ & E & $\begin{array}{c}\text { Sangat } \\
\text { Tidak } \\
\text { Baik }\end{array}$ \\
\hline
\end{tabular}

Data observasi sikap ilmiah dan res-pon respon siswa, yang pertama dihitung skor total sikap ilmiah siswa dan respon siswa terhadap komik, kemudian skor tersebut dikonversi berdasarkan skala 4 menurut Mardapi (2008, p.123).

Tabel 2. Pengubahan Skor \& Konversi

\begin{tabular}{cccc}
\hline No & \multicolumn{2}{c}{ Interval } & Kategori \\
\hline 1 & $\mathrm{X} \geq \mathrm{Yi}+$ Sbi & $\mathrm{X} \geq 3,1$ & $\begin{array}{c}\text { Sangat } \\
\text { Baik }\end{array}$ \\
\hline 2 & $\mathrm{Yi}+\mathrm{Sbi}>\mathrm{X} \geq \mathrm{Yi}$ & $2,5 \leq \mathrm{X}<3,1$ & Baik \\
\hline 3 & $\mathrm{Yi}>\mathrm{X} \geq \mathrm{Yi}-$ Sbi & $1,9<\mathrm{X}<2,5$ & Kurang \\
\hline 4 & $\mathrm{X}<\mathrm{Yi}-$ Sbi & $\mathrm{X} \leq 1,9$ & $\begin{array}{c}\text { Sangat } \\
\text { Kurang }\end{array}$ \\
\hline
\end{tabular}

Nilai gain skor diperoleh berdasarkan penghitungan terhadap data kemampuan berpikir analitis. Besarnya peningkatan kemampuan berfikir analitis dianalisis menggunakan nilai gain score dengan menggunakan persamaan (Hake, 1998, p. 8):

$$
\mathrm{g}=\frac{(\text { posttest score })-(\text { pretest score })}{\text { maximum possible score }-(\text { pretest score })}
$$

Nilai gain kemudian diklasifikasikan dengan kriteria gain skor,kategori gain score menurut (Hake, 1998, p. 8) disajikan Tabel 3.

Tabel 3. Kategori PerolehanGain Skor

\begin{tabular}{cc}
\hline Kriteria & Interval \\
\hline Tinggi & $\mathrm{g} \geq 0,7$ \\
Sedang & $0,7>\mathrm{g} \geq 0,3$ \\
Rendah & $\mathrm{g}<0,3$ \\
\hline Selaniug
\end{tabular}

Selanjutnya untuk melihat keterlaksanaan pembelajaran menggunakan media komik, dilakukan observasi mengenai keterlaksanaan pembelajaran yang tertuang dalam RPP. Data yang diperoleh diprosentase dan dideskripsikan untuk menggambarkan pembelajaran keadaan subyek 
penelitian selama pembelajaran berlangsung. Analisis selanjutnya yaitu uji statistik dengan MANOVA yang bertujuan untuk mengetahui perbedaan kemampuan berfikir analitis dan sikap ilmiah akibat adanya perlakuan penggunaan komik pada kelas eksperimen.

Data sikap ilmiah diperoleh dengan cara observasi menggunakan lembar observasi sikap ilmiah. Besarnya peningkatan pada sikap ilmiah dapat dilihat dengan membandingkan peningkatan hasil sikap ilmiah pada setiap pertemuan pembelajaran berdasarkan hasil lembar observasi.

\section{HASIL DAN PEMBAHASAN}

\section{Hasil Uji Kelayakan Produk}

Hasil penelitian ini berupa media pembelajaran IPA berbentuk komik. Untuk mengetahui kelayakan komik, dilakukan validasi produk. Validasi dilakukan oleh ahli materi, ahli media, guru IPA, dan teman sejawat. Validator ahli materi adalah dosen FMIPA yang menguasai materi IPA, sedangkan validasi ahli media dilakukan oleh salah satu dosen FBS UNY jurusan seni rupa yang menguasai ilustrasi dan komik. Selain divalidasi oleh dosen ahli, komik juga ditinjau ulang oleh praktisi yaitu guru IPA dan teman sejawat baik dari segi materi maupun media Guru IPA yang terlibat dala penilaian komik merupakan guru yang mengajar di SMP $\mathrm{N} 1$ Sentolo, sedangkan teman sejawat yang terlibat adalah 2 orang mahasiswa Pascasarjana jurusan pendidikan Sains. Hasil validasi produk oleh ahli, guru IPA, dan teman sejawat berupa penilaian draf awal produk, masukan, kritik dan saran bagi pengembangan produk.

Hasil penilaian ahli materi menunjukkan bahwa draf produk awal media komik mendapatkan rata-rata skor sebesar 4,29 dan tergolong kategori sangat baik. Sedangkan hasil penilaian ahli media menunjukkan bahwa draf produk awal media komik mendapatkan rata-rata skor sebesar 4,67 dan tergolong kategori sangat baik.

Hasil validasi guru IPA pada komponen materi memperoleh rerata skor sebesar 4,57 dengan kriteria sangat baik, sedangkan pada komponen media memperoleh skor sebesar 4,56 dengan kategori sangat baik. Selanjutnya hasil validasi dari teman sejawat pada komponen materi memperoleh rerata skor sebesar 4,64 dengan kriteria sangat baik dan pada komopenen media memperoleh skor sebesar 4, 44 dengan criteria sangat baik pula. Penilaian dari seluruh validator pada komponen materi disajikan pada Gambar 2.

Data yang disajikan pada Gambar 2 menunjukkan hasil validasi komik dari ahli materi, guru, dan teman sejawat berkategori sangat baik, dimanarata-rata skor penilaian dari ahli materi 4,29 , dari guru sebesar 4,57, dan penilaian dari teman sejawat sebesar 4,64. Hal ini menunjukkan bahwa komik yang dikembangkan memenuhi syarat sebagai salah satu bentuk media pembelajaran yang efektif.

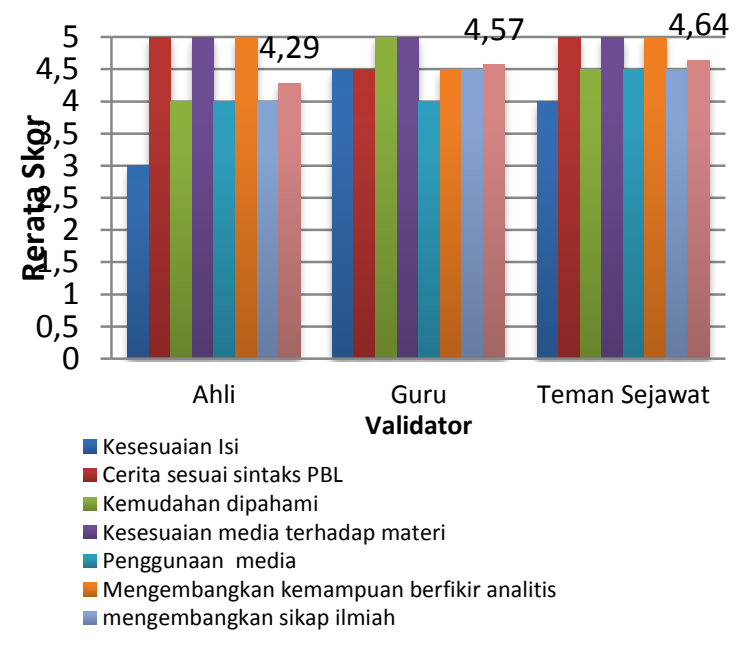

Gambar 2. Penilaian Komik pada Komponen Materi

Perolehan validasi komik oleh ahli media, guru dan teman sejawat disajikan dalam Gambar 3.

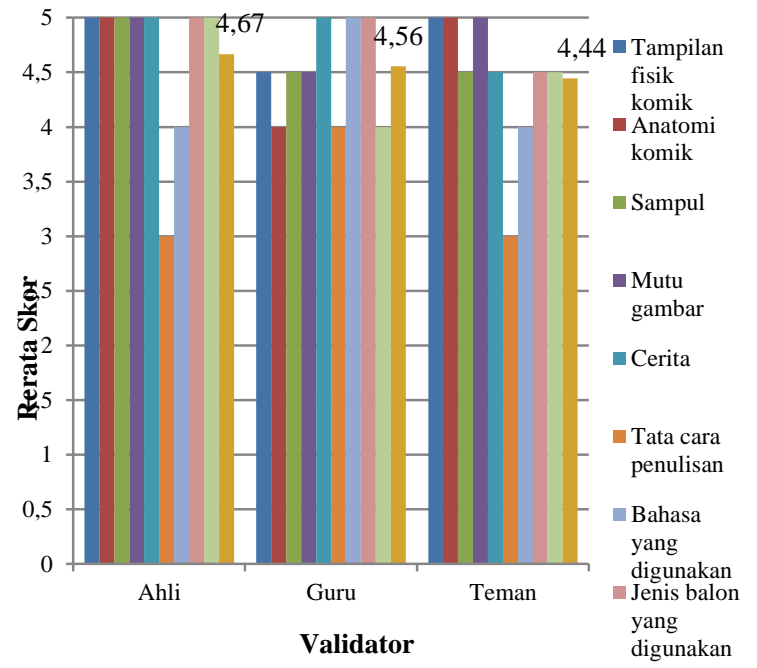

Gambar 3. Penilaian Komik pada Komponen Media

Data yang disajikan pada Gambar 3 menunjukkan hasil validasi komik dari ahli media, guru, dan teman sejawat berkategori sangat baik, 
dimana rata-rata skor penilaian dari ahli materi 4,67, dari guru sebesar 4,56, dan penilaian dari teman sejawat sebesar 4,44. Hal ini menunjukkan bahwa komik yang dikembangkan memenuhi syarat sebagai salah satu bentuk media pembelajaran yang efektif.

\section{Analisis Kemampuan Berfikir Analitis dan Sikap Ilmiah}

Perolehan nilai posttest kemampuan berfikir analitis dan nilai posttest sikap ilmiah pada kelas kontrol dan kelas eksperimen dapat disajikan pada Tabel 4 dan Tabel 5.

Tabel 4. Hasil Pretest dan Posttest Kemampuan Berfikir Analitis

\begin{tabular}{ccccc}
\hline & \multicolumn{2}{c}{ Kelas Kontrol } & \multicolumn{2}{c}{ Kelas Eksperimen } \\
\cline { 2 - 5 } & Pretest & Posttest & Pretest & Posttest \\
\hline Jumlah & 1220 & 1888 & 1250 & 2135,98 \\
Rerata & 42,7 & 65,10 & 43,10 & 73,65 \\
Gain & \multicolumn{2}{c}{0,39} & \multicolumn{2}{c}{0,51} \\
Kategori & \multicolumn{2}{c}{ Sedang } & \multicolumn{2}{c}{ Sedang } \\
\hline
\end{tabular}

Tabel 5. Hasil Pretest dan Posttest Sikap Ilmiah

\begin{tabular}{ccccc}
\hline & \multicolumn{2}{c}{ Kelas Kontrol } & \multicolumn{2}{c}{ Kelas Eksperimen } \\
\cline { 2 - 4 } & Pretest & Posttest & Pretest & Posttest \\
\hline Rerata & 22,55 & 26,72 & 23,60 & 28,53 \\
Gain & 0,36 & \multicolumn{2}{c}{0,43} \\
Kategori & \multicolumn{2}{c}{ Sedang } & \multicolumn{2}{c}{ Tinggi } \\
\hline
\end{tabular}

Selanjutnya, dari hasil pretest dan posttest sikap ilmiah dan berfikir analitis, untuk mengetahui pencapaian kemampuan berfikir analitis dan sikap ilmiah dihitung gainnya, yaitu perbandingan antara selisih nilai pretest dan posttest dengan selisih skor maksimum dan skor pretest. Rerata gain antara kelas kontrol dan eksperimen dilihat pada Gambar 4.

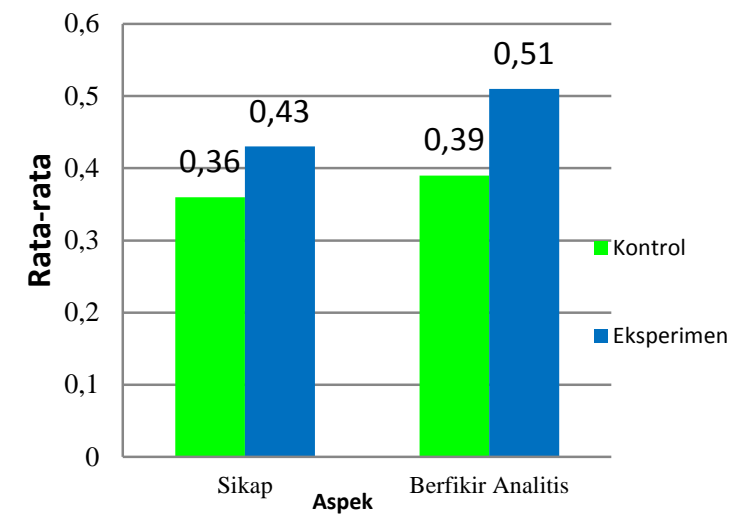

Gambar 4. Rerata Gain Kemampuan Berfikir Analitis dan Sikap Ilmiah

Data yang disajikan pada Gambar 4 menunjukkan bahwa rerata gain meningkat. Rerata gain berfikir analitis kelas eksperimen mencapai 0,51 dengan kategori sedang dan pada kelas kontrol mencapai 0,39 dengan kategori sedang. Rerata gain sikap ilmiah kelas eksperimen mencapai 0,43 dengan kategori sedang dan pada kelas kontrol mencapai 0,36 dengan kategori sedang. Peningkatan gain tersebut menunjukkan bahwa media komik efektif untuk meningkatkan kemampuan berfikir analitis dan sikap ilmiah siswa.

Perbedaan Penggunaan Komik terhadap Kemampuan Berfikir Analitis dan Sikap Ilmiah

Data kemampuan awal berfikir analitis dan sikap ilmiah, dianalisis menggunakan uji perbedaan rata-rata dua kelompok (uji t) dengan tujuan untuk mengetahui ada atau tidaknya perbedaan pada rata-rata kemampuan awal kedua kelas. Hasil uji t disajikan pada Tabel 6.

Tabel 6. Hasil Independent Samples Test

\begin{tabular}{cccc}
\hline No & Aspek & T & Sig. \\
\hline 1 & Sikap & 1,423 & 0,160 \\
2 & Berfikir Analitis & 0,265 & 0,792 \\
\hline
\end{tabular}

Tabel 6 menunjukkan bahwa sikap ilmiah memperoleh nilai $\mathrm{t}=1,42$ dengan signifikansi sebesar 0,160 . Artinya signifikansi yang diperoleh lebih besar dari 0,05. Dengan demikian Ho diterima, yang berarti tidak terdapat perbedaan kemampuan awal sikap ilmiah antara kelas eksperimen dan kontrol. Adapun untuk berfikir analitis diperoleh nilai $t=0,265$ dengan signifykansi sebesar 0,792. Artinya signifikansi yang diperoleh lebih besar dari 0,05. Dengan demikian Ho diterima, yang berarti tidak terdapat perbedaan kemampuan awal berfikir analitis antara kelas eksperimen dan kelas kontrol.

Selanjutnya karena dari tidak terdapat perbedaan kemampuan awal kedua kelas, maka untuk mengetahui perbedaan sikap ilmiah dan berfikir analitis setelah diberikan perlakuan, maka dilakukan analisis menggunakan MANOVA. Sebelum melakukan uji Manova terlebih dahulu melakukan uji prasyarat dengan derajat signifikansi setiap uji sebesar $\alpha=5 \%(0,05)$. Asumsi lain yang harus dipenuhi dalam uji MANOVA yaitu normalitas dan homogenitas varian, sebagai berikut:

\section{Normalitas Multivariat}

Asumsi normalitas bertujuan untuk melihat apakah data berasal dari populasi yang berdistribusi normal. Asumsi normalitas menggunakan SPSS 16 dengan menlihat jarak mahalonobis $\left(d_{i}^{2}\right)$. Apabila $d_{i}^{2} \leq \chi_{p, 0.50}^{2} \quad(1,38)$ maka data berasal dari populasi yang berdistribusi 
normal multivariat. Hasil uji asmusi normalitas multivariate kedua kelas disajikan pada Tabel 7.

Tabel 7.Hasil Uji Asumsi Normalitas Multivariat

\begin{tabular}{cccc}
\hline No & Kelas & $d_{i}^{2} \leq \chi_{p, 0.50}^{2}$ & Persentase \\
\hline 1. & Eksperimen & 13 & $44 \%$ \\
2. & Kontrol & 14 & $48 \%$ \\
\hline
\end{tabular}

Homogenitas Varian

Homogenitas varian menggunakan uji Levene's yang dapat dilihat pada Tabel 8.

Tabel 8. Hasil Uji Levene's (Homogenitas Varian)

\begin{tabular}{cccc}
\hline No. & \multicolumn{1}{c}{ Aspek } & F & Sig \\
\hline 1. & Berfikir Analitis & 0,252 & 0,168 \\
2. & Sikap Ilmiah & 1,247 & 0,269 \\
\hline
\end{tabular}

Hasil uji Levene's (Homogenitas Varian) menunjukkan bahwa nilai F sikap ilmiah sebesar 1,247 dengan signifikansi 0,269 sedangkan untuk berfikir analitis nilai $\mathrm{F}$ sebesar 0,252 dengan signifikansi 0,618. Ditetapkan taraf signifikansi $5 \%(\alpha=0,05)$ maka keduanya memiliki varian yang homogen karena signifikansinya lebih besar dari 0,05 sehingga MANOVA dapat dilanjutkan.

Homogenitas Matrik Varian/Covarian

Homogenitas varian/Covarian menggunakan uji Box Matrices, hasil uji Box's M tertera pada Tabel 9.

Tabel 9. Hasil Uji Box's M (Homogenitas Matrik Varian/Covarian)

\begin{tabular}{cc}
\hline Box's M & Sig \\
\hline 1,961 & 0,597 \\
\hline
\end{tabular}

Hasil SPSS diperoleh bahwa nilai Box's M sebesar 1,961 dengan signifikansi 0,597. Signifikansi yang diperoleh lebih besar dari 0,05. Hal itu menunjukkan bahwa hipotesis nol diterima, yang berarti matriks varian/covarian dari variabel dependen sama (homogen). Asumsi uji ini telah terpenuhi maka MANOVA dapat dilakukan. Hasil hipotesis uji MANOVA dapat dilihat pada Tabel 10.

Tabel 10. Hasil Hipotesis Uji Manova

\begin{tabular}{|c|c|c|}
\hline & Value & Sig \\
\hline Wilks' Lambda & 0,890 & 0,041 \\
\hline
\end{tabular}
nunjukkan bahwa pada taraf signifikansi 0,05 nilai Sig dari Wilks' Lambda sebesar 0,041. Nilai tersebut $<0,05$. Kesimpulannya terdapat perbedaan pada rata-rata kemampuan berfikir analitis dan sikap ilmiah akibat adanya perlakuan penggunaan media komik pada kelas eksperimen. Hal ini juga didukung oleh penelitian yang dilakukan Rini (2014) menunjukkan bahwa penggunaan media komik IPA berkarakter dapat meningkatkan hasil belajar siswa ranah kognitif.

Selain data kemampuan berfikir analitis, data respon siswa juga dianalisis dengan tujuan untuk melihat bagaimana respon siswa setelah belajar menggunakan media komik. Respon siswa terhadap komik dengan model PBL diproleh dari angket yang diisi oleh siswa setelah siswa melaksanakan seluruh rangkaian kegiatan pembelajaran menggunakan media komik. Respon siswa meliputi komponen materi dan media yang seluruhnya berjumlah 28 item pernyataan. Respon siswa kemudian ditabulasi dan dikonversi menggunakan skala 4. Hasil respon siswa terhadap komik disajikan pada Gambar 5.

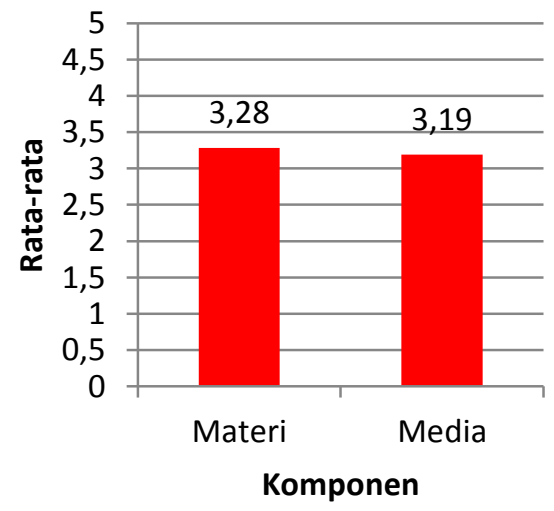

Gambar 5. Respon Siswa Terhadap Komik

Data yang disajikan pada Gambar 5 menunjukkan bahwa siswa merespon sangat positif komik yang dikembangkan. Rerata skor respon siswa pada komponen materi sebesar 3,28 yang berkategori sangat baik dan pada komponen media sebesar 3,19 yang berkategori sangat baik. Beberapa komentar dari siswa, bahwa komik dengan model PBL dapat digunakan sebagai media pembelajaran, siswa tertarik dan senang belajar menggunakan komik.

Pada pembelajaran menggunakan media komik, dinilai juga keterlaksanaannya yang tertuang pada RPP. Keterlaksanaan RPP diperoleh dari hasil observasi yang dilakukan selama tiga kali pertemuan. Hasil keterlaksanaan RPP dapat dilihat pada Tabel 11. 
Tabel 11. Keterlaksanaan RPP

\begin{tabular}{|c|c|c|c|c|}
\hline \multirow[t]{2}{*}{ No } & \multirow[t]{2}{*}{$\begin{array}{c}\text { Tahap } \\
\text { Kegiatan }\end{array}$} & \multicolumn{3}{|c|}{$\begin{array}{c}\text { Keterlaksanaan } \\
\text { Pembelajaran Pertemuan ke- } \\
(\%)\end{array}$} \\
\hline & & I & II & III \\
\hline 1 & Pendahuluan & 100 & 100 & 100 \\
\hline 2 & Inti & 100 & 100 & 100 \\
\hline 3 & Penutup & 100 & 100 & 100 \\
\hline \multicolumn{2}{|c|}{ Keterlaksanaan } & 100 & 100 & 100 \\
\hline \multicolumn{5}{|c|}{$\begin{array}{l}\text { Berdasarkan Tabel 11, keterlaksanaan } \\
\text { RPP pada pertemuan I, II, dan III diperoleh } \\
\text { persentase sebesar } 100 \% \text {, hal itu menandakan } \\
\text { bahwa tahap pembelajaran menggunakan media } \\
\text { komik model PBL terlaksana dengan baik dan } \\
\text { sesuai yang direncanakan. }\end{array}$} \\
\hline
\end{tabular}

\section{SIMPULAN DAN SARAN}

\section{Simpulan}

Berdasarkan analisis data dan pembahasan dapat ditarik kesimpulan bahwa karakteristik media komik yang dikembangkan adalah: Judul komik adalah Jernih Airku Sehat Lingkunganku yang merupakan integrasi dari KD 4.3, KD 7.3, dan KD 7.4, alur ceritanya berbasis model PBL, yang memuat aspek: menyajikan masalah, mengorganisasikan siswa untuk meneliti, membantu siswa untuk meneliti, mempresentasikan hasil, serta refleksi dan evaluasi, penyusunan cerita dalam komik memenuhi indikator kemampaun berfikir analitis yaitu: merinci suatu masalah, mencari hubungan antar aspek, membedakan objek, mengorganisasikan (menentukan metode alat, bahan, kesimpulan), dan mengatribusikan (menentukan pendapat atau tujuan dari aktivitas), tokoh dalam komik diperankan melalui sikap ilmiah yaitu sikap berfikir terbuka dan sikap ingin tahu, media komik dicetak menggunakan kertas jenis art paper 160 gram yang berukuran A5 dan dengan sampul ivory 260 gram.

Media komik dengan model PBL yang dikembangkan layak digunakan dengan kategori sangat baik ditinjau dari aspek media dan materi berdasarkan penilaian ahli, guru IPA, dan teman sejawat. Komik dengan model PBL efektif dalam meningkatkan kemampuan berfikir analitis dan sikap ilmiah. Hal itu dapat diketahui adanya pengaruh yang signifikan akibat perlakuan penggunaan media komik model PBL pada kelas eksperimen.

\section{Saran}

Berdasarkan hasil penelitian pengembangan ini, maka dapat disarankan bahwa: Penggunaan komik dengan model PBL ini se- baiknya dilaksanakan dengan rentang waktu yang lebih panjang sehingga siswa dapat optimal memperoleh pengalaman yang mendalam tentang kegiatan dalam komik. Bagi guru IPA, penelitian pengembangan ini dapat untuk meningkatkan kemampuan berfikir analitis, ketercapain konsep, dan sikap ilmiah siswa. Sebagai tindak lanjut, guru dapat mengembangkan komik sejenis dengan tema yang berbeda. Pemanfaatan produk di dalam pembelajaran dapat dipadukan dengan model, metode, pendekatan lain yang berbeda.

\section{DAFTAR PUSTAKA}

Anderson, L.W., \& Krathwohl, D.R. (2010). Kerangka landasan untuk pembelajaran, pengajaran, dan asessmen. (Terjemahan Agung Prihantoro). New York: David Mckay. (Buku asli diterbitkan tahun 1956).

Azwar, S. (2011). Sikap manusia: Teori dan pengukurannya. Yogyakarta: Pustaka Pelajar.

Bundu, P. (2006). Penilaian keterampilan proses dan sikap ilmiah dalam pembelajaran sains $S D$. Jakarta: Depdiknas

Chiapetta, L. E., \& Koballa, R. T. (2010). Science instruction in the middle and secondary schools developing fundamental knowledge and skills. New York: Pearson Education, Inc.

Daryanto. (2010). Media pembelajaran. Yogyakarta: Gava Media.

Fatonah, S., \& Prasetyo, Z. K. (2014). Pembelajaran sains. Yogyakarta: Penerbit Ombak.

Gall, M., Gall, J., \& Borg, W. (2011). Educational Research. Educational Research (Vol. 1). Retrieved from http://books.google.nl/books?id=Mlwz9rA wZJ8C

Hake, R. R. (1998). Interactive-engagement versus traditional methods: A sixthousand-student survey of mechanics test data for introductory physics courses. American Journal of Physics, 66(1), 6474. http://doi.org/10.1119/1.18809

Hamriah. (2013). Kurikulum tingkat satuan pendidikan dan implementasinya pada madrasah aliyah negeri di Kota Makassar. Jurnal Diskursus Islam, Vol.1, No.3, 329365

Harty, H., \& Beall, D. (1984). Toward the 


\section{Jurnal Inovasi Pendidikan IPA, 2 (2), 2016 - 155}

Devy Indah Lestari, Anti Kolonial Projosantoso

development of a children's science curiosity measure. Journal of Research in Science Teaching, 21(4), 425-436. http://doi.org/10.1002/tea.3660210410

Kemdikbud. (2013). Kurikulum 2013. Jakarta: Kemendikbud.

Kuswaya, W. S. (2012). Taksonomi kognitif: perkembangan ragam berpikir. Bandung: PT Remaja Rosdakarya.

Mardapi, D. (2008). Teknik penyusunan instrumen tes dan non tes. Yogyakarta: Mitra Cendikia.

Moore, K. D. (2009). Effective instructional strategies: From theory to practice $\left(2^{\text {nd }}\right.$ ed.). Los Angeles: Sage Publications.

Noll Webb, E., Balasubramanian, G., ỎBroin, U., \& Webb, J. M. (2012). WHAM! POW! Comics as user assistance. Journal of Usability Studies, 7(3), 105-117. Retrieved from http://www.usabilityprofessionals.org.

Nugraha, E. A., Yulianti, D., \& Khanafiyah, S. (2012). Pembuatan bahan ajar komik sains inkuiri materi benda untuk mengembangkan karakter siswa kelas IV SD. Unnes Physics Education Journal, 1(2), 60-68. http://doi.org/10.15294/UPEJ.V1I2.1379

Nur, M., \& Muslimin. (2007). Hakikat sains. Buku Ajar Prodi PGSD Program Pascasarjana Universitas Negeri Yogyakarta. Tidak diterbitkan.

OECD. (2013). Pisa 2012 result: What students know and can do, 1, 1-556.

Sudjana, N., \& Rivai, A. (2011). Media pengajaran. Bandung: Sinar Baru.

WCES. (2012). Development Of Teachers' Learning Management Emphasizing On Analytical Thinking In Thailand. Procedia Social and Behavioral Science, 46, 33393344.

Widyawati, A., \& Prodjosantoso, A. K. (2015). Pengembangan media komik IPA untuk meningkatkan motivasi belajar dan karakter peserta didik SMP. Jurnal Inovasi Pendidikan IPA, 1(1), 24-35. http://doi.org/10.21831/JIPI.V1I1.4529 